\title{
Improving dissolution profile of poorly water-soluble drug using non-ordered mesoporous silica
}

\author{
Jyotsana R. Madan 1, *, Shronavi Patil 1, Dyandevi Mathure 1, Santosh P. Bahirat 1, \\ Rajendra Awasthi ${ }^{2}$, Kamal Dua 3,4 \\ 1 Department of Pharmaceutics, Smt. Kashibai Navale College of Pharmacy, Savitribai Phule Pune University, Pune, \\ Maharashtra, India \\ 2 NKBR College of Pharmacy \& Research Centre, Meerut, 245 206, Uttar Pradesh, India \\ 3 School of Pharmacy and Biomedical Sciences, The University of Newcastle, Newcastle, NSW 2308, Australia \\ 4 Discipline of Pharmacy, Graduate School of Health, University of Technology Sydney, Ultimo NSW 2007, Australia \\ * Correspondence: jyotsna.madan@sinhgad.edu (J.R.M.); ORCID No: 0000-0001-6663-1890
}

Received: 30 June 2017; Revised: 6 September 2017; Accepted: 7 September 2017

\begin{abstract}
The aim of the study was to increase dissolution rate of atorvastatin by the use of mesoporous silica SYLOID ${ }^{\circledR} 244$ FP. The poorly soluble drug atorvastatin was adsorbed on and/or into SYLOID ${ }^{\circledR} 244$ FP in the ratios $1: 1$, 1:1.1.5, 1:2, 1:2.5, 1:3 and 1:3.5 via a wetness impregnation method. The absence of crystalline form and presence of hydrogen bond interaction between atorvastatin and SYLOID ${ }^{\circledR} 244$ FP is done by Fourier-transform infrared spectroscopy (FTIR) and differential scanning calorimetry (DSC). The atorvastatin loaded matrix lacked in the crystalline form of atorvastatin and it showed improvement in the dissolution rate of ATC. The flowability of the atorvastatin loaded matrix powder was evaluated by bulk density, Carr's index and angle of repose. This matrix was then processed into a tablet by direct compression method. A $3^{2}$ full factorial design was applied to investigate the combined effect of two formulation variables - volume of ethanol and amount of SYLOID ${ }^{\circledR} 244$ FP. The tablets were evaluated for hardness, friability, drug content and drug dissolution studies. The solubility of atorvastatin-loaded matrix was increased up to 4.28 times. Atorvastatin tablet prepared from drug-loaded silica may provide a feasible approach for development of an oral formulation for this poorly water-soluble drug.
\end{abstract}

KEYWORDS: Non-ordered mesoporous silica; atorvastatin; wetness impregnation method; factorial design; bioavailability.

\section{INTRODUCTION}

Pharmaceutical scientists are constantly developing new strategies to improve the drug dissolution rate so as to enable the effective oral delivery of poorly water soluble drugs. Various strategies have been widely investigated to enhance the dissolution of poorly water soluble drugs such as solid dispersions, emulsion based drug delivery, hydrotropy, inclusion complexation, solid lipid nanoparticles, and so on [1-5]. In recent years, considerable research efforts have been directed towards the development of porous carriers for increasing the dissolution of relatively insoluble drugs [6]. One of the pharmaceutically exploited porous adsorbent includes mesoporous silica. Porous silica is a porous material that has been commonly used as a pharmaceutical excipient. Several grades of porous silicate having different characteristics such as particle size, pore size, specific surface area are commercially available. Since the discovery of mesoporous $(2-50 \mathrm{~nm})$ silica materials in the 1990s, the synthesis and application of mesoporous silica have received substantial attention due to their unique features such as, inert nature, high surface area, large pore volume, good compatibility and high physicochemical stability [7].

Mesoporous silica as a drug carrier was first evaluated by Vallet-Regi et al [8] Adsorption onto mesoporous silica (MS) is a new enabling technology that improves the performance of poorly water soluble drugs by improving their dissolution rate and solubility and thereby enhancing oral bioavailability [9, 10]. A concentrated drug solution is loaded into pores through capillary forces.

How to cite this article: Madan JR, Patil S, Mathure D, Bahirat SP, Awasthi R, Dua K. Improving dissolution profile of poorly watersoluble drug using non-ordered mesoporous silica. Marmara Pharm J. 2018; 22 (2): 249-258. 
In the present study, we selected SYLOID ${ }^{\circledR} 244 \mathrm{FP}$ (S244) silica as a carrier due to its unique particle structure and morphology. It has a highly developed network of pores that provide access to the ultra high surface area, an adjustable pore size in the range of 2.5 to $3.7 \mu \mathrm{m}$, and a high drug-loading capacity [11-16], which defines its performance as a suitable dissolution enhancement agent. SYLOID ${ }^{\circledR} 244$ FP was combined with excipients to develop modified tablet using direct compression method.

Statins are a class of cholesterol lowering drugs which have a low dissolution rate and bioavailability, warranting the preparation of novel formulations $[17,18]$. Atorvastatin calcium (ATC) a BCS Class II drug, one of the world's top-selling statin, has an absolute oral bioavailability of $12 \%$ ( $\%$ F) from a $40 \mathrm{mg}$ oral dosage form. The oral bioavailability of ATC is mainly limited by, solubility and dissolution rate. Hence, it was proposed to enhance the dissolution of ATC using mesopororus silica as a carrier.

The main objective of the present work was to develop atorvastatin calcium tablet formulation with improved drug dissolution properties by using adsorption based drug loading on or into SYLOID ${ }^{\circledR} 244 \mathrm{FP}$ mesoporous silica. An additional objective was to find out the minimum effective quantity of S244 required to enhance solubility. This work is also expected to expand the use of silica-based non-ordered mesoporous materials as drug delivery systems.

\section{RESULTS AND DISCUSSION}

\subsection{Determination of solubility}

The solubility of ATC as observed in distilled water and phosphate buffer ( $\mathrm{pH}$ 6.8) was found to be $1.01 \times 10^{-1} \pm 0.087 \mathrm{mg} / \mathrm{ml}$ and $1.9 \times 10^{-1} \pm 0.076 \mathrm{mg} / \mathrm{ml}$, respectively.

\subsection{Loading of ATC on and/ or into SYLOID ${ }^{\circledR} 244 \mathrm{FP}$ silica}

The ATC loaded S244 particles formed after the solvent immersion process were collected and dried using a rotary film evaporator. The major advantage of this method is that it reduces the risk of crystallization of the drug on the surface of the carriers, fixing amounts of the loaded drug and providing industrial scalability for loading the drug into porous materials [26]. Table 1 indicates that ATC is loaded on and/ or into S244 and consequently there is an increase in solubility. A ratio of 1:1.25 (ATC: S244) showed maximum loading and solubility of the drug.

Table 1. Results of phase solubility study.

\begin{tabular}{|c|c|c|c|}
\hline $\begin{array}{l}\text { Amount of } \\
\text { ATC (mg) }\end{array}$ & $\begin{array}{c}\text { Amount of SYLOID }{ }^{\circledR} 244 \text { FP } \\
(\mathrm{mg})\end{array}$ & $\begin{array}{l}\text { Amount of } \\
\text { ethanol (ml) }\end{array}$ & Solubility $(\mathrm{mg} / \mathrm{ml})$ \\
\hline 20 & $20(1: 1)$ & 1.5 & $2.90 \times 10^{-1} \pm 0.038$ \\
\hline 20 & $30(1: 1.5)$ & 1.5 & $3.30 \times 10^{-1} \pm 0.047$ \\
\hline 20 & $40(1: 2)$ & 1.5 & $4.03 \times 10^{-1} \pm 0.061$ \\
\hline 20 & $50(1: 2.5)$ & 1.5 & $5.42 \times 10^{-1} \pm 0.042$ \\
\hline 20 & $60(1: 3)$ & 1.5 & $5.26 \times 10^{-1} \pm 0.042$ \\
\hline 20 & $70(1: 3.5)$ & 1.5 & $5.13 \times 10^{-1} \pm 0.052$ \\
\hline 20 & - & - & $1.90 \times 10^{-1} \pm 0.076$ \\
\hline
\end{tabular}

\subsection{Characterization of ATC-S244 matrix}

\subsubsection{Fourier transform infra red spectroscopy (FTIR)}

FTIR analysis was employed to characterize the possible interaction in the ATC-S244 matrix. FTIR spectrum of ATC and S244FP are shown in Figure 1. FTIR spectrum of ATC-S244 matrix showed the combined individual characteristic peaks of ATC $\left(1317.44 \mathrm{~cm}^{-1} \mathrm{C}-\mathrm{N}\right.$ stretching, $1654.03 \mathrm{~cm}^{-1} \mathrm{C}=\mathrm{C}$ bending) and S244 carrier (1111 cm-1 Si-O-Si stretching and $472 \mathrm{~cm}^{-1} \mathrm{O}-\mathrm{Si}-\mathrm{O}$ bending), indicating that ATC was physically rather than chemically adsorbed on the outer surface of the porous silica particles (Figure 1c). 

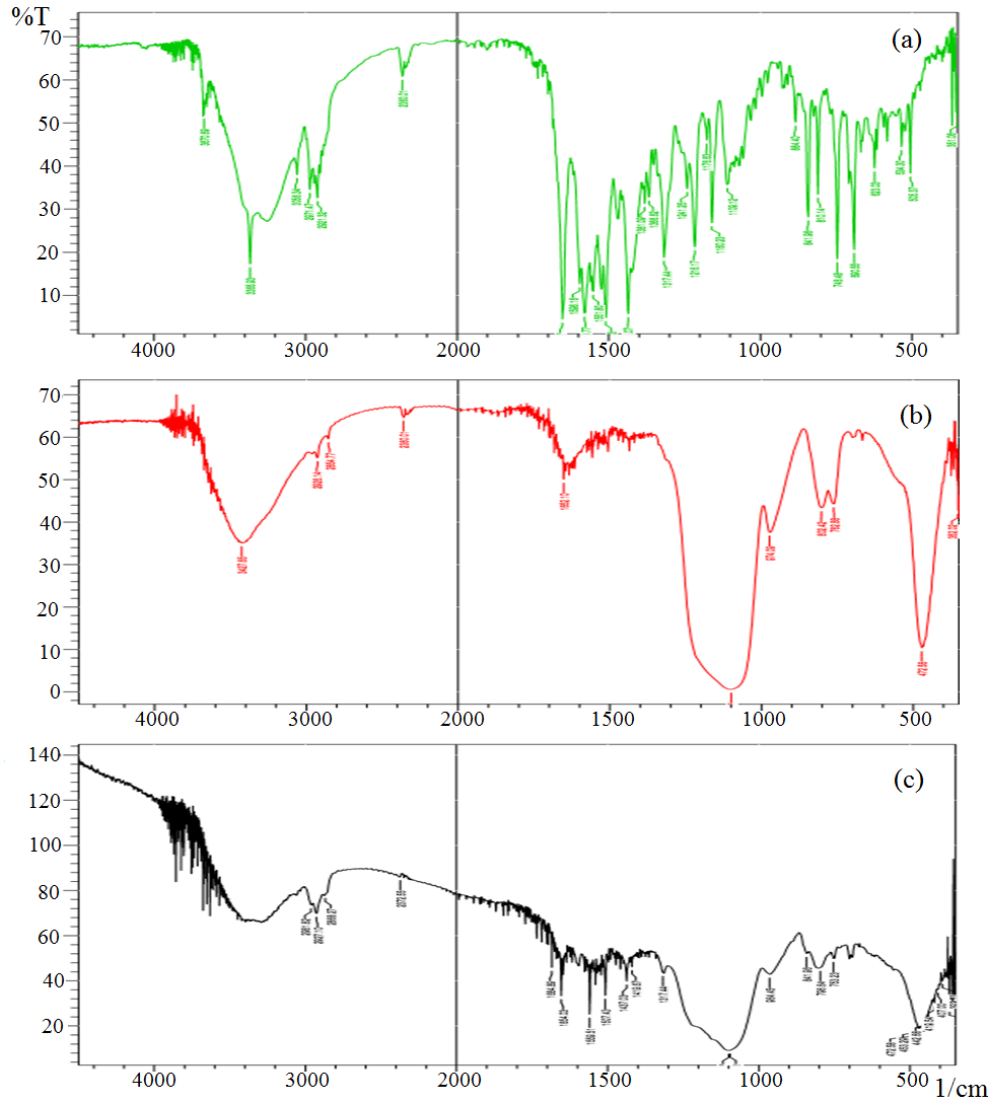

Figure 1. FTIR spectrum of atorvastatin (a), SYLOID ${ }^{\circledR} 244$ FP (b), and ATC- S244 matrix (c).

\subsubsection{Differential scanning calorimetry analysis (DSC)}

The DSC thermogram of ATC is shown in Figure 2a. The onset temperature was reported in the graph. DSC thermogram of ATC shows endothermic melting peak at $158^{\circ} \mathrm{C}$. S244 carrier was amorphous without any distinctive peak. DSC thermogram of ATC-S244 matrix is shown in Figure 2b. The thermogram indicates that ATC had totally lost its crystalline nature through formation of ATC-S244 matrix.

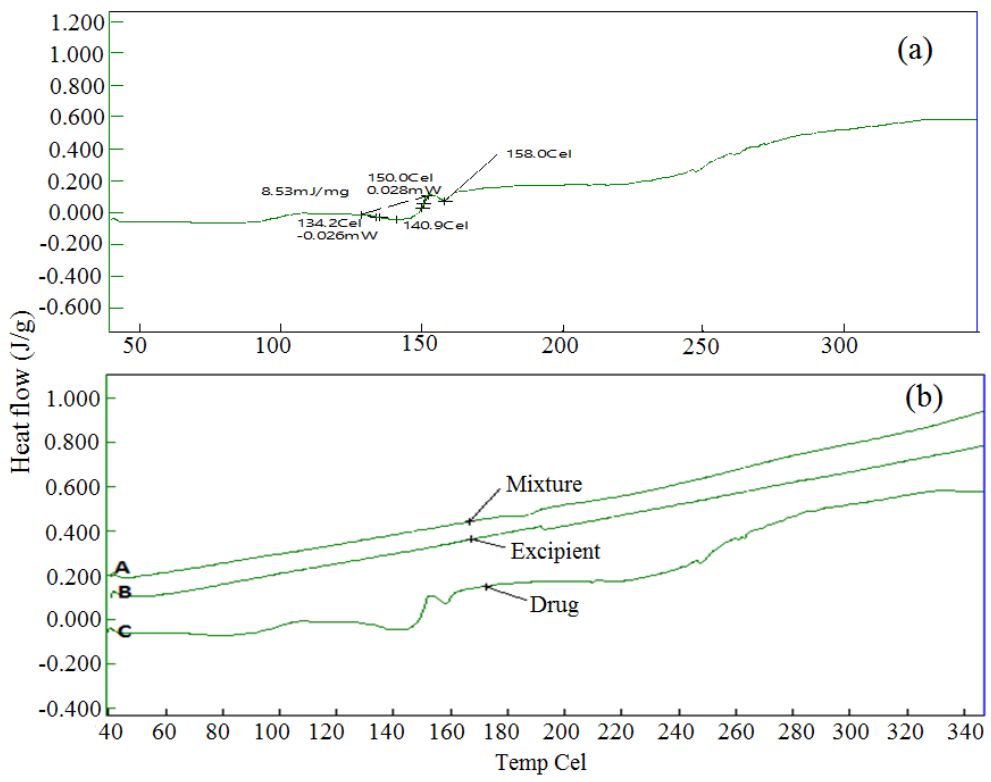

Figure 2. Differential scanning calorimetry thermogram of ATC (a) and mixture (ATC- S244 matrix), excipient (SYLOID $\left.{ }^{\circledR} 244 \mathrm{FP}\right)$ and drug (ATC) (b). 


\subsubsection{Phase solubility study}

The results of phase solubility studies are presented in Table 1 . The data indicate a rise in solubility of ATC in phosphate buffer when loaded in and/or on S244. The highest solubility $\left(5.42 \times 10^{-1} \pm 0.042 \mathrm{mg} / \mathrm{ml}\right)$ was achieved in the matrix containing ATC: S244 at 1: 2.5 ratio when compared to pure ATC $\left(1.9 \times 10^{-1} \pm 0.076\right.$ $\mathrm{mg} / \mathrm{ml})$.

\subsubsection{Comparison between in vitro dissolution of atorvastatin tablet prepared by direct compression method with and without $S 244$}

Percent cumulative drug release $v$ s time (min) of ATC from the prepared tablets without S244 and with S244 was plotted (Figure 3). Figure 3 indicates that the percentage cumulative release of tablets containing S244 was greater than that of the tablets without S244. All results indicate Mean \pm SD $(n=3)$.

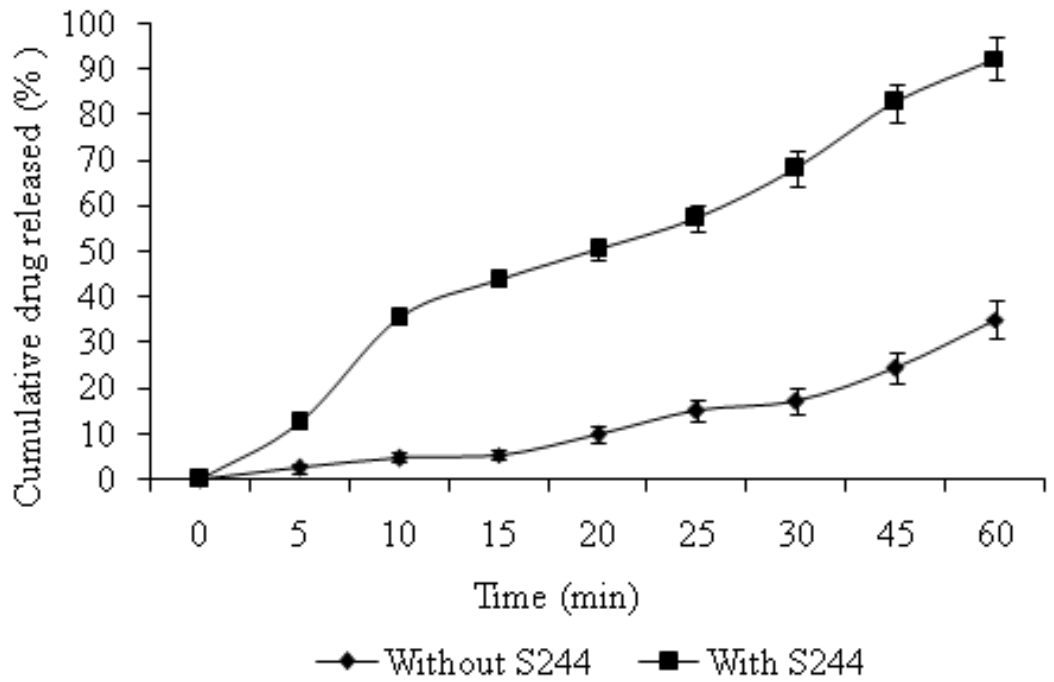

Figure 3. Comparative percentage cumulative release of atorvastatin from tablets with and without S244 in phosphate buffer $(\mathrm{pH} 6.8)$ at $37^{\circ} \mathrm{C}($ mean $\pm \mathrm{SD}, \mathrm{n}=3)$.

\subsubsection{Factorial design}

A $3^{2}$ randomized full factorial design was used in the present study. In this design, 2 factors were evaluated, each at 3 levels, and experimental trials were performed for all 9 possible combinations. The concentration of volume of ethanol $\left(\mathrm{X}_{1}\right)$ and S244 $\left(\mathrm{X}_{2}\right)$ were chosen as independent variables in $3^{2}$ full factorial designs, while solubility and percentage drug release were taken as dependent variables. The concentrations of other ingredients were fixed based on preliminary trials. The formulation layout for the factorial design batches (F1-F9) is shown in Table 4. Pre-compression parameters for F1-F9 Batches were studied and are shown in Table 4.

Table 4. Pre-compression micromeritic properties of F1-F9 batches.

\begin{tabular}{ll}
\hline Parameter & Range \\
\hline Bulk Density $\left(\mathrm{g} / \mathrm{cm}^{3}\right)$ & $0.51 \pm 0.011-0.57 \pm 0.22$ \\
Tapped Density $\left(\mathrm{g} / \mathrm{cm}^{3}\right)$ & $0.62 \pm 0.210-0.68 \pm 0.24$ \\
Carr's Index & $12.66 \pm 0.58-19.80 \pm 0.06$ \\
Hausner Ratio & $<1.25$ \\
Angle of repose & $18.24 \pm 0.32^{\circ}-22.50 \pm 0.13^{\circ}$ \\
\hline
\end{tabular}

On compression, post compression parameters for F1-F9 batches were evaluated. The hardness of the tablets was in the acceptable range of 3.7 to $4.1 \mathrm{~kg} / \mathrm{cm}^{2}$. Friability was in the range of 0.51 to $0.82 \%$. Drug content of all tablets was between 95.35 to $99.61 \%$. The percentage cumulative release for all batches \{Mean \pm $\mathrm{SD}(\mathrm{n}=3)\}$ is shown in Figure 4. 


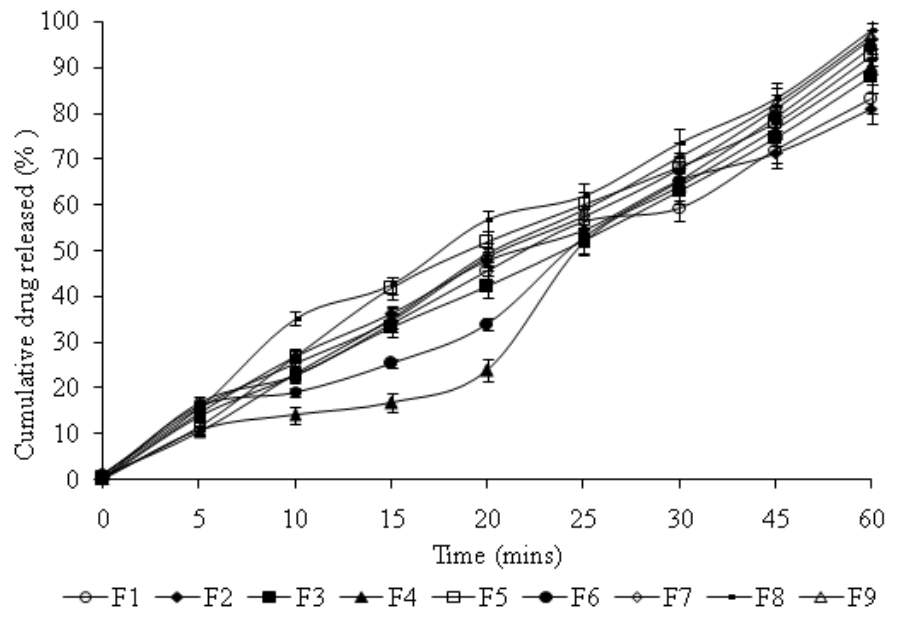

Figure 4. In vitro drug release profiles of different batches (Batch F1 to F9) of non-ordered mesoporous silica tablets containing atorvastatin in phosphate buffer $(\mathrm{pH} 6.8)$ at $37^{\circ} \mathrm{C}($ mean $\pm \mathrm{SD}, \mathrm{n}=3)$.

The main effects of the volume of ethanol $\left(X_{1}\right)$ and amount of S244 $\left(X_{2}\right)$ represent the average result, when the factors were changed one at a time from their low to high values. The interaction terms $\left(X_{1} X_{2}\right)$ show how the response changes when two factors are simultaneously changed. The release profile for all 9 batches showed a variation. The data indicate that the release profile of the drug is strongly dependent on the selected independent variables.

The fitted quadratic equations relating the responses solubility and percentage cumulative drug release, to the transformed factor are shown in the equation 2 and 3 . The polynomial equations can be used to draw conclusions after considering the magnitude of coefficient and the mathematical sign it carries (i.e., negative or positive) so as to indicate either synergistic or an antagonistic effect. The resulted equations for dependent variables in terms of coded factors are presented below:

Solubility $(\mathrm{mg} / \mathrm{ml})=+6.14+1.61 \mathrm{X}_{1}+0.53 \mathrm{X}_{2}+0.030 \mathrm{X}_{1} \mathrm{X}_{2}+0.028 \mathrm{X}_{1}^{2}-0.78 \mathrm{X}_{2}{ }^{2}$

Cumulative percent release $=+68.55+3.95 \mathrm{X}_{1}+1.24 \mathrm{X}_{2}-0.32 \mathrm{X}_{1} \mathrm{X}_{2}+0.65 \mathrm{X}_{1}^{2}-4.01 \mathrm{X}_{2}^{2}$

\subsubsection{Response surface plots}

Three-dimensional plots for the measured responses were presented to determine the change of the response surface. These types of plots are useful in the study of the effects of two factors on the response at one time. Figure $5 \mathrm{a}$ and Figure $5 \mathrm{~b}$ shows that the solubility of ATC and percentage cumulative release from tablets increases with increasing amount of S244 from 45-50 mg. However, further increasing S244 to $55 \mathrm{mg}$ does not increase both solubility and percentage cumulative release. A high level of ethanol used to form matrix $(2 \mathrm{ml})$ was found to increase both the dependent variables.
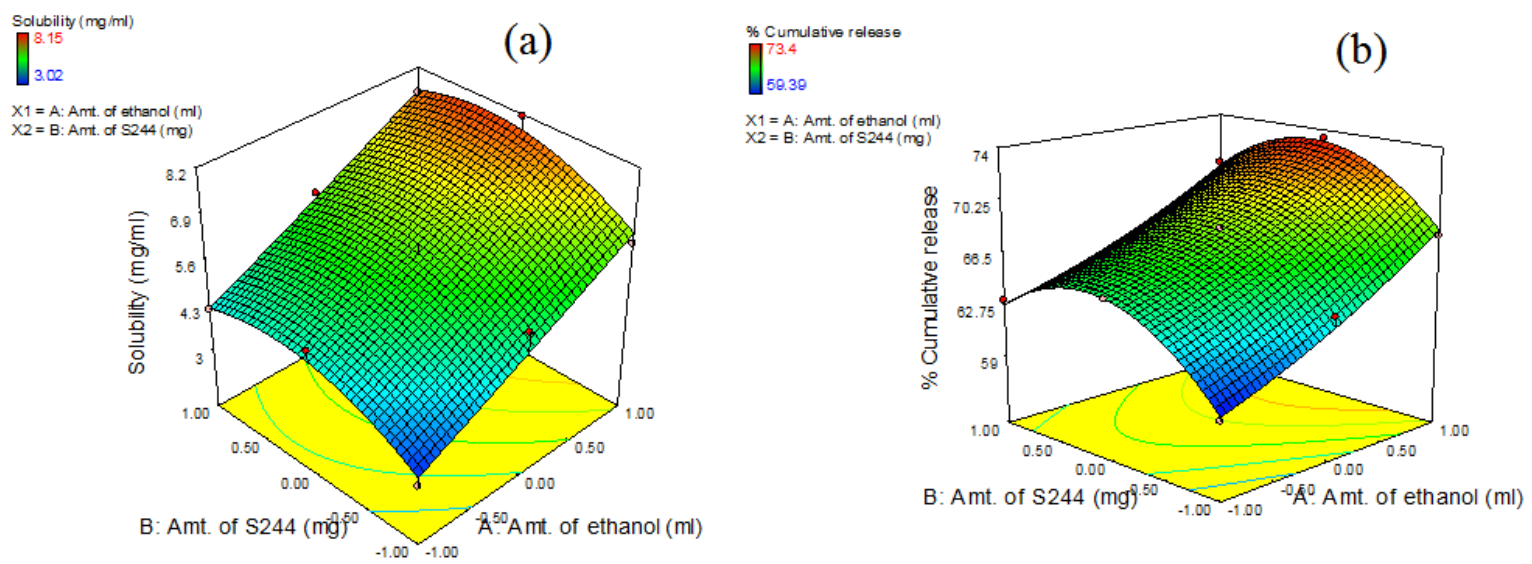

Figure 5. Response surface plots showing the influence of amount of ethanol $\left(X_{1}\right)$ and SYLOID ${ }^{\circledR} 244 \mathrm{FP}\left(\mathrm{X}_{2}\right)$ on solubility (a) and percentage cumulative drug release (b) of atorvastatin. 


\section{CONCLUSION}

In the present research work ATC was loaded into non-ordered mesoporous silica, SYLOID ${ }^{\circledR} 244 \mathrm{FP}$. Further, the ATC- S244 matrix was compressed into tablets and highest solubility enhancement was formed in the lower drug loading ratio, 1:1.2.5 (ATC: S2440) matrix. The results of a $3^{2}$ full factorial design revealed that the amount of S244 and volume of ethanol significantly affect the dependent variables. It was concluded that the dissolution rate of poorly water-soluble drug ATC can be improved significantly using the mesoporous silica carriers.

\section{MATERIALS AND METHODS}

\subsection{Materials}

Atorvastatin calcium (ATC) was received as a gift sample from Accent Pharma Ltd., Jammu, India. SYLOID $^{\circledR} 244$ FP silica (S244) was gifted by Grace Davison Discovery Sciences, Germany. Microcrystalline cellulose, crospovidone, sodium lauryl sulphate and ethanol were obtained from Research-Lab Chem industries, Mumbai, India. Lactose, potassium dihydrogen phosphate (monobasic) and sodium hydroxide were obtained from SD fine chemicals, Mumbai, India. All the other chemicals and reagents used were of analytical grade.

\subsection{Methods}

\subsubsection{Determination of solubility}

Saturation solubility of ATC was determined in distilled water and phosphate buffer, $\mathrm{pH} 6.8$ (dissolution media of ATC). Accurately weighed amount of disodium hydrogen phosphate $(28.80 \mathrm{~g})$ and potassium dihydrogen phosphate ( $11.45 \mathrm{~g}$ ) was dissolved in $900 \mathrm{ml}$ of distilled water. The $\mathrm{pH}$ was adjusted to $\mathrm{pH}$ 6.8; further sufficient amount of distilled water was added to produce $1000 \mathrm{ml}$. The solution was degassed before use. All media were prepared and excess of ATC was added to each of them and kept in an incubator shaker at a speed of $200 \mathrm{rpm}$ for $24 \mathrm{~h}$ at $37^{\circ} \mathrm{C}$. After $24 \mathrm{~h}$, the solution was centrifuged at $2000 \mathrm{rpm}$ for $15 \mathrm{~min}$. Supernatants were diluted with a respective media (i.e. distilled water and phosphate buffer $\mathrm{pH}$ 6.8). The absorbance was measured at $250 \mathrm{~nm}$ using UV visible spectrophotometer (SHIMADZU, V-630, Japan) and the solubility was calculated [19-20].

\subsubsection{Loading of ATC on and/ or into SYLOID ${ }^{\circledR} 244$ FP silica}

A wetness impregnation method was used to load ATC on and/or into the S244 [21]. S244 in varying quantity was added to a $1.5 \mathrm{ml}$ ethanol solution containing $20 \mathrm{mg}$ of ATC (Table 1). Ethanol was used as loading solvent because it is safe, nontoxic, and can dissolve large amounts of ATC. Further, the mixture was sonicated using probe sonicator (Sonapros PR-250, Oscar Ultrasonics, Mumbai, India) in a closed vial for 10 min. The resultant mixture was brought to adsorption equilibrium under magnetic stirring at room temperature $\left(25^{\circ} \mathrm{C}\right)$ for $24 \mathrm{~h}$ in order to achieve maximum drug loading in the S244 pore channels. Finally, the solvent was evaporated at $50^{\circ} \mathrm{C}$ on a rotary evaporator (Heidolph, UK) until dry in order to remove the ethanol completely. The ATC loading in the matrix was determined by FTIR, DSC and phase solubility studies.

\subsubsection{Characterization of ATC S244 matrix}

Fourier-transform infrared spectroscopy (FTIR), differential scanning calorimetry (DSC) and phase solubility study methods were used to evaluate the ATC-S244 matrix.

\subsubsection{Fourier-transform infrared spectroscopy}

Fourier-transform infrared spectrum (FTIR) of ATC, S244 and ATC-S244 matrix was recorded over a range $4000-400 \mathrm{~cm}^{-1}$ to study principal peaks using a FTIR spectrophotometer (Shimadzu Affinity-1). The scans were examined for the presence of principal peaks of ATC, shifting and masking of ATC peaks due to S244 and the appearance of new peaks.

\subsubsection{Differential scanning calorimetry analysis (DSC)}

The DSC thermograms of pure ATC, S244 and ATC-S244 matrix was recorded using a differential scanning calorimeter (DSC 4000 Perkin Elmer, USA). The instrument was calibrated using indium $\left(156^{\circ} \mathrm{C}\right)$, tin $\left(232^{\circ} \mathrm{C}\right)$ and zinc $\left(419.5^{\circ} \mathrm{C}\right)$ as internal standards. An empty aluminium pan was used as a reference. Each 
sample was accurately weighed into an aluminum pan and sealed. The probes were heated from $40-350^{\circ} \mathrm{C}$ at a rate of $10^{\circ} \mathrm{C} / \mathrm{min}$ under nitrogen atmosphere.

\subsubsection{Phase solubility study}

The phase solubility method was used to examine the effect of S244 on the solubility of ATC. Solubility measurements were carried out as per the method reported by Higuchi and Connors [22] using phosphate buffer ( $\mathrm{pH}$ 6.8). Twenty mg of ATC was dissolved in ethanol solution, in six beakers. To each beaker, S244 was added as indicated in Table 1. Phosphate buffer, pH $6.8(10 \mathrm{ml})$ was added in the beaker and the solution was stirred for $24 \mathrm{~h}$ and filtered through Whatman grade 41 filter paper. Absorbance was measured at $250 \mathrm{~nm}$ using UV visible spectrophotometer (SHIMADZU, V-630, Japan) and solubility in various matrix formed was calculated and compared with pure ATC solubility in $6.8 \mathrm{pH}$ phosphate buffer.

\subsubsection{Preparation of tablets}

\subsubsection{Preparation of ATC tablets by direct compression method without S244}

ATC, microcrystalline cellulose as a binder, crosspovidone as a disintegrant, and lactose as a diluent were mixed in geometric proportion to get a uniform mixture. This mixture was passed through sieve no \# 60 and sodium lauryl sulphate was added as lubricant. Tablets were compressed using flat round punch of $8 \mathrm{~mm}$ sizes on a Rimek compression machine.

\subsubsection{Preparation of ATC tablets by direct compression method with $S Y L O I D{ }^{\circledR} 244 F P$}

ATC $(20 \mathrm{mg})$ was dissolved in ethanol $(1.5 \mathrm{ml})$ at room temperature. S244 $(50 \mathrm{mg})$ was added and the suspension was shaken for $1.5 \mathrm{~h}$ using mechanical shaker. The solvent was evaporated under reduced pressure in a water bath at $45-50^{\circ} \mathrm{C}$ for $15 \mathrm{~min}$ using a rotary film evaporator (Heidolph, UK). The samples were further dried under vacuum at room temperature $\left(25^{\circ} \mathrm{C}\right)$. Microcrystalline cellulose, crosspovidone and lactose were mixed with above dried samples. This final mixture was passed through sieve no \# 60 and sodium lauryl sulphate was added as lubricant. Tablets were compressed by $8 \mathrm{~mm}$ sized flat round punchs using Rimek tablet compression machine. These tablets were further subjected to in-vitro dissolution studies and percentage cumulative release was compared to tablets prepared with and without S244. Table 2 indicates the final formula per tablet.

Table 2. Formula of tablets prepared with and without S244.

\begin{tabular}{lll}
\hline Ingredients *(mg) & With S244 & Without S244 \\
\hline Atorvastatin(mg) & 20 & 20 \\
SYLOID $^{\circledR}$ 244 FP(mg) & 50 & - \\
MCC $(\mathrm{mg})$ & 20 & 4.5 \\
Crosspovidone(mg) & 4.5 & 1.5 \\
SLS(mg) & 1.5 & 44 \\
Lactose (q.s) & 120 & 120 \\
\hline${ }^{*}$ Quantities are for one tablet & &
\end{tabular}

\subsubsection{Full factorial design}

A $3^{2}$ randomized factorial design was adopted to further optimize the formulation variables. In this design, two factors were evaluated each at 3 levels and experimental trials were performed for all 9 possible combinations [23]. The amount of S244 ( $\left.\mathrm{X}_{1}\right)$ and volume of ethanol $\left(\mathrm{X}_{2}\right)$ were selected as independent variables. Tablets were prepared by the direct compression method with S244. Solubility of ATC and percentage cumulative release were selected as the dependent variables. The formulation of factorial batches (F1 to F9) is shown in Table 3. Amount of microcrystalline cellulose $(20 \mathrm{mg})$, crosspovidone $(4.5 \mathrm{mg})$, SLS (1.5 mg) was same for all batches. The final weight of tablet was made up to $120 \mathrm{mg}$ using lactose as diluent.

\subsubsection{Pre-compression parameters for batches F1-F9}

Powder blends of F1-F9 batches were evaluated for various pre-compression parameters such as bulk density, compressibility index, Hausner's ratio and angle of repose. 


\subsubsection{Post-compression parameters for batches F1-F9}

\subsubsection{Hardness test}

The hardness of tablets was determined using Monsanto hardness tester. Three tablets were randomly selected from each batch and the hardness was determined. The mean and standard deviation value was calculated [24].

\subsubsection{Friability}

The percentage friability of tablets was determined by using Roche friabilator. The percentage friability of tablets less than $1 \%$ was considered as acceptable [25]. Twenty tablets were initially weighed $\left(\mathrm{W}_{\text {initial }}\right)$ and transferred into USP tablet friabilator. The friabilator was operated at $25 \mathrm{rpm}$ for $4 \mathrm{~min}$ and run up to 100 revolutions. The tablets were weighed again $\left(\mathrm{W}_{\text {final }}\right)$. The percentage friability was calculated using following equation:

$$
\text { Friability }(\%)=\frac{\mathrm{W}_{\text {initial }}-\mathrm{W}_{\text {final }}}{\mathrm{W}_{\text {initial }}} \times 100
$$

Table 3. Formulation of the factorial batches (F1 to F9).

\begin{tabular}{|c|c|c|c|c|c|}
\hline \multirow{2}{*}{ Batches } & \multicolumn{2}{|c|}{ Independent variables } & \multicolumn{2}{|c|}{ Actual values } & \multirow{2}{*}{ Solubility $(\mathrm{mg} / \mathrm{ml})^{*}$} \\
\hline & $X_{1}$ & $X_{2}$ & $X_{1}(\mathrm{ml})$ & $X_{2}(\mathrm{mg})$ & \\
\hline F 1 & -1 & -1 & 1.0 & 45 & $3.02 \times 10^{-1} \pm 0.0040$ \\
\hline F 2 & -1 & 0 & 1.0 & 50 & $4.24 \times 10^{-1} \pm 0.0057$ \\
\hline F 3 & -1 & +1 & 1.0 & 55 & $4.86 \times 10^{-1} \pm 0.0084$ \\
\hline F 4 & 0 & -1 & 1.5 & 45 & $5.40 \times 10^{-1} \pm 0.0071$ \\
\hline F 5 & 0 & 0 & 1.5 & 50 & $5.46 \times 10^{-1} \pm 0.0061$ \\
\hline F 6 & 0 & +1 & 1.5 & 55 & $6.00 \times 10^{-1} \pm 0.0039$ \\
\hline F 7 & +1 & -1 & 2.0 & 45 & $6.14 \times 10^{-1} \pm 0.0087$ \\
\hline F 8 & +1 & 0 & 2.0 & 50 & $8.15 \times 10^{-1} \pm 0.0057$ \\
\hline F 9 & +1 & +1 & 2.0 & 55 & $7.48 \times 10^{-1} \pm 0.0049$ \\
\hline
\end{tabular}

$\mathrm{X}_{1}$ : volume of ethanol, $\mathrm{X}_{2}$ : amount of SYLOID ${ }^{\circledR} 244 \mathrm{FP}(\mathrm{S} 244)$

*Values are expressed as mean $\pm S D, n=3$

\subsubsection{Drug content uniformity}

Twenty tablets were weighed and crushed in a mortar. The powder equivalent to $100 \mathrm{mg}$ of ATC was dissolved in $100 \mathrm{ml}$ of phosphate buffer ( $\mathrm{pH}$ 6.8) to obtain a $1000 \mu \mathrm{g} / \mathrm{ml}$ solution. The solution was shaken periodically and kept for $24 \mathrm{~h}$ for salvation of drug completely. The mixtures were filtered, appropriately diluted, and absorbance was measured at $\lambda_{\max } 250 \mathrm{~nm}$ against blank reference. The drug content in each tablet was calculated using the standard calibration curve of atorvastatin in phosphate buffer $\mathrm{pH} 6.8$.

\subsubsection{In-vitro dissolution studies}

In vitro drug releases study of the tablets was carried out using USP - type I dissolution apparatus (Basket type). The dissolution medium, $900 \mathrm{ml}$, phosphate buffer ( $\mathrm{pH}$ 6.8) was placed into the dissolution flask maintaining the temperature at $37 \pm 0.5^{\circ} \mathrm{C}$. One tablet was placed in each flask of dissolution apparatus. The apparatus was allowed to run at rpm of 75 for $2 \mathrm{~h}$. Samples $(2 \mathrm{ml})$ were withdrawn after every $0,5,10,15,20,25,30,45,60 \mathrm{~min}$ interval. Samples were filtered through $10 \mu \mathrm{m}$ filter. The fresh dissolution medium was replaced every time to maintain sink condition. The collected samples were analyzed at $250 \mathrm{~nm}$ using UV visible spectrophotometer (SHIMADZU, V-630, Japan).

\subsubsection{Mathematical Model}

Following statistical model incorporating interactive and polynomial terms was used to evaluate the responses (equation 1):

$Y_{i}=\beta_{0}+\beta_{1} X_{1}+\beta_{2} X_{2}+\beta_{3} X_{1} X_{2}+\beta_{4} X_{1}^{2}+\beta_{5} X_{2}^{2}+\beta_{6} X_{1} X_{2}^{2+} \beta_{7} X_{2} X_{1}^{2} \quad \ldots$ (eq. 1 ) 
where $Y i$ is the level of response variable; $\beta i$ is the regression coefficient; $X_{1}$, and $X_{2}$ stand for the main effect; $X_{1} X_{2}$ is the interaction terms of the main effects; and $X_{1}^{2}$, and $X_{2}^{2}$ are quadratic terms of the independent variables that are used to simulate the curvature in the designed space.

Author contributions: Concept - J.R.M., K.D.; Design - J.R.M., S.P., D.M., S.P.B., R.A., K.D.; Supervision - J.R.M., K.D.; Resource - J.R.M., S.P., D.M., S.P.B., K.D.; Materials - J.R.M., S.P., D.M., S.P.B., R.A.; Data Collection and/or Processing J.R.M., S.P., S.P.B., R.A., K.D.; Analysis and/or Interpretation - J.R.M., S.P., D.M., R.A.; Literature Search - J.R.M., S.P., D.M., S.P.B.; Writing - J.R.M., R.A.; Critical Reviews - J.R.M., S.P., D.M., S.P.B., R.A., K.D.

Conflict of interest statement: The authors declared no conflict of interest in the manuscript.

\section{REFERENCES}

[1] Madan JR, Pawar KT, Dua K. Solubility enhancement studies on lurasidone hydrochloride using mixed hydrotropy. Int J Pharm Investig. 2015;5(2):114-120.

[2] Singh R, Bharti N, Madan J, Hiremath SN. Characterization of cyclodextrin inclusion complexes - A review. J Pharm Sci Technol. 2010;2(3):171-183.

[3] Madan J, Sudarshan B, Kadam V, Dua K. Formulation and development of self-microemulsifying drug delivery system of pioglitazone hydrochloride. Asian J Pharm. 2014;27-34.

[4] Madan JR, Ghuge NP, Dua K. Formulation and evaluation of proniosomes containing lornoxicam. Drug Deliv Transl Res. 2016;6(5):511-518.

[5] Madan JR, Khude PA, Dua K. Development and evaluation of solid lipid nanoparticles of mometasone furoate for topical delivery. Int J Pharma Investig. 2014;4(2):60-64.

[6] Ahuja G, Pathak K. Porous carriers for controlled/modulated drug delivery. Indian J Pharm Sci. 2009;71(6):599-607.

[7] Wang Y, Zhao Q, Hu Y, Sun L, Bai L. Ordered nanoporous silica as carriers for improved delivery of water insoluble drugs: a comparative study between three dimensional and two dimensional macroporous silica. Int J Nanomedicine. 2013;8:4015-4031.

[8] Vallet-Regí M, Balas F, Arcos D. Mesoporous materials for drug delivery. Angew Chem Int Ed Engl. 2007;46(40):75487558.

[9] Zhao Z, Wu C, Zhao Y, Hao Y, Liu Y, Zhao W. Developmemt of an oral push- pull osmotic pump of fenofibrateloaded mesoporous silica nanoparticles. Int J Nanomedicine. 2015;10:1691-1701.

[10] Vialpando M, Smulders S, Bone S, Jager C, Vodak D, Van Speybroeck M, Verheyen L, Backx K, Boeykens P, Brewster ME, Ceulemans J, Novoa de Armas H, Van Geel K, Kesselaers E, Hillewaert V, Lachau-Durand S, Meurs G, Psathas P, Van Hove B, Verreck G, Voets M, Weuts I, Mackie C. Evaluation of three amorphous drug delivery technologies to improve the oral absorption of flubendazole. J Pharm Sci. 2016;5:2782-2793.

[11] Coasne B, Galarneau A, Pellenq RJ, Di Renzo F. Adsorption, intrusion, and freezing in porous silica; the view from the nanoscale. Chem Soc Rev. 2013;42:414-417.

[12] Tarn D, Ashley CE, Xue M, Carnes EC, Zink JI, Brinker CJ. Mesoporous silica nanoparticle nanocarriers: biofunctionality and biocompatibility. Acc Chem Res. 2013;46 (3):792-801.

[13] Hillerstrom A, Andersson M, Samuelsson J, van Stam J. Solvent strategies for loading and release in mesoporous silica. Colloid Interface Sci Commun. 2014;3:5-8.

[14] Santosh PB, Neeraj R. Increasing the oral bioavailability of poorly water-soluble valsartan using nonordered mesoporous silica microparticles. Asian J Pharm. 2016;10(2):S86-S95.

[15] Kiekens F, Eelen S, Verheyden L, Daems T, Martens J, Van Den Mooter G. Use of ordered mesoporous silica to enhance the oral bioavailability of ezetimibe in dogs. J Pharm Sci. 2012;101(3):1136-1144.

[16] Jammaer JAG, Aerts A, D’Haen J, Seo J W, Martens JA. Convenient synthesis of ordered mesoporous silica at room temperature and quasi-neutral pH. J Mater Chem. 2009;19:190-198.

[17] Tiwari R, Pathak K. Statins therapy: A review on conventional and novel formulation approaches. J Pharm Pharmacol. 2011;63:983-998.

[18] Shayanfar A, Ghavimi H, Hamishehkar H, Jouyban A. Coamorphous atorvastatin calcium to improve its physicochemical and pharmacokinetic properties. J Pharm Pharm Sci. 2013;16(4):577-587.

[19] Maheshwari RK, Jagwani Y. Mixed hydrotropy: Novel science of solubility enhancement. Indian J Pharm Sci. 2011;73:179-183 
[20] Jayakumar C, Morais AP. Solubility enhancement of theophylline drug using different solubilization techniques. International Journal of Pharmaceutical Sciences. 2012;2:7-10.

[21] Kinnari P, Makila E, Heikkila T, Salonen J, Hirvonen J, Santos HA. Comparison of mesoporous silicon and nonordered mesoporous silica materials as drug carriers for itraconazole. Int J Pharm. 2011;414:148-156.

[22] Higuchi T, Connors KA. Phase-solubility techniques. Adv Anal Chem Instr. 1965;4:117-122.

[23] Patel DM, Patel MM. Optimization of Fast dissolving etoricoxib tablets prepared by sublimation technique. Indian J Pharm Sci. 2008;70:71-76.

[24] Lachman L, Libermann HA, Kanig JL. The theory and practice of industrial pharmacy, third ed., New Delhi: Varghese Publishing House, 1991.

[25] Madan J, Sharma AK, Singh R. Fast dissolving tablets of aloe vera gel. Trop J Pharm Res. 2009;8(1):63-70.

[26] Limnell T, Santos HA, Makila E, Heikkila T, Salonen J, Murzin DY, Kumar N, Laaksonen T, Peltonen L, Hirvonen J. Drug delivery formulations of ordered and nonordered mesoporous silica: Comparison of three drug loading methods. J Pharm Sci. 2011;100:3294-3306.

This is an open access article which is publicly available on our journal's website under Institutional Repository at http://dspace.marmara.edu.tr. 